\title{
Chemical Composition and Radical Scavenging Activity of Citrus limon Peel Essential Oil
}

\author{
MONA GHOORCHIBEIGI ${ }^{1}$, KAMBIZ LARIJANI ${ }^{1 *}$, \\ PARVIZABEROOMAND AZAR ${ }^{1}$, KARIM ZARE $^{1}$ and IRAJ MEHREGAN ${ }^{2}$
}

\begin{abstract}
1Department of Chemistry, Science and Research Branch, Islamic Azad University, Tehran, Iran. ${ }^{2}$ Department of Biology, Science and Research Branch, Islamic Azad University, Tehran, Iran.

*Corresponding author E-mail: larijani_k@yahoo.com
\end{abstract}

http://dx.doi.org/10.13005/ojc/330153

(Received: November 04, 2016; Accepted: December 10, 2016)

\begin{abstract}
The water distillated essential oil of Citruslimon collected from Ramsar, Province of Mazandaran, North of Iran collected in December 2013, was analyzed using gas chromatography (GC) and gas chromatography-mass spectroscopy (GC-MS). The yield of oil was $0.23 \% \mathrm{w} / \mathrm{w}$. Twenty-one components representing $100 \%$ of the essential oil were characterized. Limonene $(61.4 \%)$, b-pinene $(13.1 \%)$ and g-terpinene $(11.3 \%)$ were identified as the main constituents in the volatile oil. The antioxidant ability of the oil was examined by free radical scavenging method using 2,2-diphenyl-1-picrylhydrazyl (DPPH) radical at different concentration of the oil. The Citruslimon oil exhibited free-radical-scavenging properties with IC50 value of $284.71 \mu \mathrm{g} \mathrm{ml}^{-1}$.
\end{abstract}

Keywords: Citrus limon, Essential oil, Radical Scavenging, DPPH.

\section{INTRODUCTION}

Essential oils are complex mixture of volatile compounds which consist of terpenes and their oxygenated derivatives such as aldehydes, alcohols and ketones with high potential bioactivity like antibacterial, antifungal and antioxidant that extracted mainly using steam and hydrodistillation ${ }^{1,2}$.

The genus Citrus which belonged to Rutaceae family is represented in Iran by several species such as $C$. sinensis, C. medica, C. limon, C. nobelis, C. aurantifolia and C. aurantium. Citrus fruits are the most common subtropical plants in the world with a numerous variation due to frequent bud mutation, interspecific and intergeneric hybridization. In Iran, the phylogeny of many citrus variants is remained unknown ${ }^{3}$. In last decade, the essential oil of Citrus limon were the subject of previous study and limonene, a hydrocarbon monotrepene, is dominant constituents which shown sufficient antifungal activity ${ }^{4}$. The oil of $C$. limon was shown acceptable activity against Anopheles stephensi (malaria agent) compare to N, Ndiethyl-3-methylbenzamide (Deet) as a standard synthetic repellent ${ }^{5}$. 
This study deals with the composition characterization and antioxidant activity using free radical scavenging method of Citrus limon essential oil with cultivated in the North of Iran for the first time.

\section{MATERIAL AND METHODS}

\section{Plant Material}

The fruit of Citruslimon were harvested in from Ramsar, province of Mazandaran, North of Iran in December 2013. The collected material was identified in the Citrus Research Institute of Iran (Ramsar, Mazandaran).

\section{Essential Oil Extraction}

The Citruslimonfruits were washed with cold water and peeled. The peels of fruits were dried in shade and grinded. $100 \mathrm{gr}$ of grinded peels were subjected to hydrodistillation using a Clevenger type apparatus for $3 \mathrm{~h}$. The pale yellowish oil was dried over anhydrous $\mathrm{Na}_{2} \mathrm{SO}_{4}$ and kept in $4^{\circ} \mathrm{C}$ until analysis ${ }^{6}$.

\section{Table1: Chemical composition of Citrus limon essential oil}

\begin{tabular}{lll}
\hline Compounds & KI & (\%) \\
\hline Nonane & 900 & 0.1 \\
a-thujene & 930 & 0.6 \\
a-pinene & 939 & 2.4 \\
sabinene & 975 & 2.3 \\
b-pinene & 979 & 13.1 \\
myrcene & 991 & 1.6 \\
a-terpinene & 1017 & 0.3 \\
limonene & 1029 & 61.4 \\
z-b-ocimene & 1037 & 0.3 \\
E-b-ocimene & 1050 & 0.2 \\
g-trpinene & 1060 & 11.3 \\
terpinolene & 1089 & 0.6 \\
a-terpineol & 1188 & 0.4 \\
neral & 1238 & 1.1 \\
geranial & 1267 & 1.5 \\
neryl acetate & 1362 & 0.5 \\
geranyl acetate & 1381 & 0.3 \\
b-caryophyllene & 1419 & 0.4 \\
E-a- bergamotene & 1435 & 0.6 \\
bicyclogermacrene & 1500 & 0.2 \\
b-bisabolene & 1506 & 0.8 \\
\hline
\end{tabular}

Qualitative analysis of $\boldsymbol{C}$. limon oil components

The qualitative analysis was done using a Hewlett-Packard 6890 GC coupled to a HewlettPackard 5973 mass selective detector equipped with a HP-5MS (30m $\times 0.25 \mathrm{~mm}, 0.32 \mu \mathrm{m}$ film thickness) column. Oven temperature was programmed from $60^{\circ} \mathrm{C}(3 \mathrm{~min})$ to $230^{\circ} \mathrm{C}$ at $6^{\circ} \mathrm{C} / \mathrm{min}$, and the final temperature kept for $3 \mathrm{~min}$. split (1:30) injector temperature was $250^{\circ} \mathrm{C}$. Carrier gas was $\mathrm{He}$ $(99.999 \%)$ at $1 \mathrm{ml} / \mathrm{min}$ flow rate. The volume of injected sample was $1.0 \mu$ l of diluted oil in hexane. The mass spectra were achieved at ionization energy $70 \mathrm{eV}$, in the electronic ionization (EI) mode. Ion source temperature was $230^{\circ} \mathrm{C}$. Scan mass range was adjusted of $\mathrm{m} / \mathrm{z}$ 40-650.

The constituents of essential oil were characterized based on their similarity of their mass spectra with those gathered in the Wiley library, or reported in the literature and their relative retention Index (RRI), calculated in relation to the retention time of a series of alkanes $\left(\mathrm{C}_{7}-\mathrm{C}_{20}\right)$ as reference chemicals, in comparison with those of the chemical compounds gathered by Adams data ${ }^{7}$.

\section{Quantitative analysis of $C$. limon oil components}

The isolated oil was dissolved in n-hexane, and $1.0 \mu \mathrm{l}$ was injected to a Hewlett-Packard 6890

Table 2: \%RSA and absorbance of different concentration of Citrus limonessential oil

Oil concentration absorbance \%RSA $\left(\mu \mathrm{g} \mathrm{ml}^{-1}\right)$

\begin{tabular}{lcc}
\hline $\mathrm{DPPH}^{\prime}$ (blank) & 1.35 & - \\
1 & 0.93 & 31.11 \\
5 & 0.92 & 31.85 \\
10 & 0.91 & 32.59 \\
50 & 0.8 & 40.74 \\
100 & 0.81 & 40 \\
200 & 0.76 & 43.7 \\
400 & 0.61 & 54.81 \\
600 & 0.47 & 65.18 \\
800 & 0.26 & 80.74 \\
1000 & 0.01 & 99.26 \\
Positive control & & \\
Ascorbic acid & 0.64 & 37.6 \\
$\left(100 \mathrm{\mu g} \mathrm{ml}^{-1}\right)$ & & \\
\hline
\end{tabular}




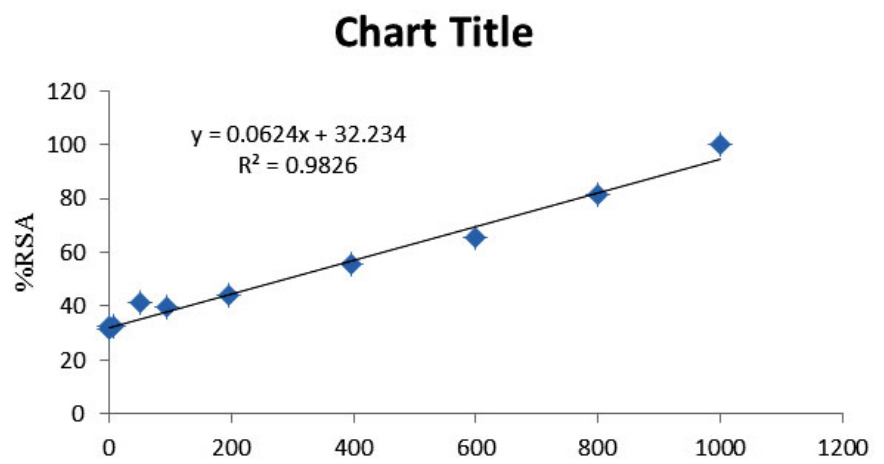

Fig. 1: Relation of Citrus limon essential oil concentration and \%RSA

gas chromatograph equipped with HP-5 capillary column $(30 \mathrm{~m} \times 0.25 \mathrm{~mm}$, film thickness $0.32 \mu \mathrm{m})$. The operating conditions were as follows: oven temperature program from $60^{\circ} \mathrm{C}(3 \mathrm{~min})$ to $230^{\circ} \mathrm{C}$ at $6^{\circ} \mathrm{C} / \mathrm{min}$ heating rate, kept for $3 \mathrm{~min}$ at the final temperature, split injection ratio 1:30, carrier gas nitrogen, flow rate $1 \mathrm{~mL} / \mathrm{min}$, temperature of injector and detector (FID) fixed at $260^{\circ} \mathrm{C}$ and $280^{\circ} \mathrm{C}$, respectively.

\section{Antioxidant activity of $C$. limonessential oil}

The stable organic radical DPPH has been widely used in the determination of the antioxidant activity of different plant extracts. This procedure is based on the reduction of DPPH solutions in the presence of plant extract. DPPH solutions show a strong absorption band at $517 \mathrm{~nm}$ appearing a deep violet color. The ability of $C$. limon essential oil to quench reactive species by hydrogen $\left(\mathrm{H}^{+}\right.$ions $)$ donation was measured through DPPH radical scavenging activity assay. Activity was measured as relative decrease absorbance at $517 \mathrm{~nm}$ as reaction between DPPHÿ and The oil. Antioxidant activity was evaluated with $\% 50\left(\mathrm{IC}_{50}\right)^{8}$. A $2 \mathrm{ml}$ of $0.1 \mathrm{mM}$ DPPHÿ methanol solution with $2 \mathrm{ml}$ sample with 1 , $5,10,50,100,200,400,600,800$ and $1000 \mathrm{~g} \mathrm{ml}^{-1}$ concentration with shaking. After the solution was incubated for $30 \mathrm{~min}$ at $25^{\circ} \mathrm{C}$ in dark, the decrease in the absorbance at $517 \mathrm{~nm}$ was measured. Control contained methanol instead of sample solution. The radical scavenging activity percentage (\%RSA) was calculated by the blow equation. Ascorbic acid (100 $\mu \mathrm{g} \mathrm{ml}^{-1}$ ) was used as positive control.

$$
\% R S A=\left[\left(\mathrm{OD}_{\mathrm{DPPH}^{-}}-\mathrm{OD}_{\text {sample }}\right) / \mathrm{OD}_{\mathrm{DPPH}}\right] \times 100
$$

\section{RESULT AND DISCUSSIONS}

The pale yellowish essential oil of Citrus limon was obtain in the yield of $0.23 \% \mathrm{w} / \mathrm{w}$. The chemical composition of Citrus limonessential oil was listed in Table 1. Twenty one components, representing $100 \%$ of the total oil, were identified in Citrus limonessential oil. Limonene (61.4\%), b-pinene (13.1\%) and g-terpinene (11.3\%) were the main constituents. The oil contained $94.1 \%$ hydrocarbon monoterpenes, $3.8 \%$ oxygenated monoterpenes, $2.0 \%$ hydrocarbon sesquiterpenes and $0.1 \%$ non-terpenes compounds.

\section{DPPHÿ radical scavenging activity}

DPPH radical-scavenging activity percentage (\%RSA) was reported in Table 2. The values of DPPHÿ \%RSA were presented in table 2 and the relation of extract concentration and \%RSA was presented in figure 1 .

As shown in figure 3 , the $\mathrm{IC}_{50}$ concentration could be calculated using equation of curve $\left(y=0.0624 x+32.234, R^{2}=0.9826\right)$ by replacing the amount of 50 instead of $Y$. The Citruslimon showed the $\mathrm{IC}_{50}$ at $284.71 \mathrm{\mu g} \mathrm{ml}^{-1}$. The amount of \%RSA for the concentration of $100 \mathrm{\mu g} \mathrm{ml}^{-1}$ of essential oil and ascorbic acid (40.00 and $37.6 \%$, respectively) were showed close free radical scavenging activity.

\section{CONCLUSION}

Demands for natural substance are increasing by food, cosmetic and medicine industry due to consumer's needs. So the importance of studies on essential oils lies not only in the 
identification of their constituents but also in the possibility of linking the chemical contents with particular bioactive functional properties. The capacity of essential oils to prevent disease is an interest of researchers. There is a strong need to understand the preventive effect of essential oils for counter acting oxidative damages. Our studysuggested that essential oil of cituslimon peel can be considered as an auxiliary supplement.

\section{ACKNOWLEDGMENT}

The authors are grateful to Mr. Nima Mohhamadi (ZakariaRazi Laboratory Complex, Science and Research Branch, Islamic Azad University, Tehran, Iran) for free radical scavenging tests.

\section{REFERENCES}

1. Mahalwal, V.S.; Ali, M. J. Essent. Oil Bearing Plants, 2003, 6, 31-35.

2. Joshi, A.; Sharma, A.; R.K. Bachheti, R.K.; Pandey, D.P. Orient. J. Chem., 2016, 32, 331340.

3. Mozaffarian, V. A dictionary of Iranian plants names, FarhangMo'aser Publishers, Tehran, Iran, 1998.

4. Viuda-Martos, M.; Ruiz-Navajas, Y.;FernándezLópez, J.; Pérez-Álvarez, J.Food Control, 2008, 19, 1130-1138.
5. Oshaghi, M.A.; Ghalandari, R.; Vatandoost, H.; Shayeghi, M.; Kamali-nejad, M.; TourabiKhaledi, H.; Abolhassani, M.; Hashemzade, M. Iranian J. Publ. Health, 2003, 32, 47-52.

6. Al-Humaidi, J.; Orient. J. Chem., 2015,31, 2265-2270.

7. Adams R P, Identification of EO components by gas chromatography/mass spectroscopy, Carol Stream IL: Allured Publishing Co. 2001.

8. Aghajani, Z.; Akhbari, M.; Esmaeili, B.Orient. J. Chem. 2014, 30, 181-185. 